\title{
Metal Based-oxide Nanoparticles Assisted the Uptake of the Essential Elements and Phytoremediation of Populus Alba : Essential Metabolic Processes and Genetic Stability
}

\author{
Mohamed F. Ahmed \\ Ain Shams University Faculty of Agriculture \\ Mostafa A. Ibrahim \\ NanoFab Technology Company \\ Ahmed S. Mansour \\ Cairo University National Institute of Laser Enhanced Sciences \\ Ahmed N. Emam ( $\square$ ahmed.gsc.ndp@gmail.com ) \\ National Research Centre https://orcid.org/0000-0002-4762-1600 \\ Ashraf B. Abd El-Razik \\ Ain Shams University Faculty of Agriculture \\ Eman Tawfik \\ Helwan University Faculty of Science
}

\section{Research Article}

Keywords: Populus alba, Nano-metal-oxides, micronutrients, RAPD-PCR, Toxicity, Genetic variation

Posted Date: December 6th, 2021

DOI: https://doi.org/10.21203/rs.3.rs-947444/v1

License: (ㅇ) (1) This work is licensed under a Creative Commons Attribution 4.0 International License. Read Full License 


\section{Abstract}

The present study evaluated the phytoremediation activities of Populus alba upon using nano metal-based-oxides (i.e., $\mathrm{Fe}_{2} \mathrm{O}_{3}, \mathrm{ZnO}$, and $\mathrm{Mn}_{2} \mathrm{O}_{3}$-NPs) as analogues of three main heavy metals $\mathrm{Fe}, \mathrm{Zn}$ and $\mathrm{Mn}$ exist in soil as micronutrients at three different concentrations (i.e., 20,40 , and $60 \mathrm{mg} / \mathrm{L}$ ) compared to the control. The as-prepared nanoparticles have been prepared via co-precipitation method. In addition, the physico-chemical properties were investigated using transmission electron microscopy, Fourier transform infrared spectra, X-ray diffraction and dynamic light scattering techniques. Overall, a significant difference in the biomass production-related parameters such as fresh weight, shoot length, root length, and root number compared to control upon the treatment with micronutrients-based nano-metal-oxides (i.e., $\mathrm{Mn}_{2} \mathrm{O}_{3}>\mathrm{Fe}_{2} \mathrm{O}_{3}>\mathrm{ZnO} \mathrm{NPs}$, respectively), except a significant increase in the root number of Populus alba plant upon their treatment with $\mathrm{ZnO}$ NPs compared to other prepared nano-metal-oxides and control. Also, a remarkable increase in the chlorophyll index was monitored upon treatment with $\mathrm{Fe}_{2} \mathrm{O}_{3}$ than other used $\mathrm{Mn}_{2} \mathrm{O}_{3}$ and $\mathrm{ZnO} \mathrm{NPs}$, respectively. Moreover, RAPD-PCR bioassays were applied and the actual 6 primers showed a genetic variation percentage of $34.17 \%$ indicating that Populus alba is highly genetically stable even in a highly contaminated environment/soil. All these data enhance the idea of using the Populus alba plant in phytoremediation and heavy metal uptake as micronutrients to clean up the surroundings.

\section{Introduction}

Heavy metals are naturally occurring elements with a high atomic weight and a density around 5-fold that of water (Tchounwou et al. 2012). Because of their toxicity, endurance in the environment, and bio-accumulative nature, heavy metals are well-known environmental contaminants (Ali et al. 2019). In addition, their existence at concentrations higher than the environmental normal levels, which originated from human activities (i.e., mining, chemical, metal processing industries, and other allied industries) leads to be interference with the functioning of vital cellular components that exist in plant, animal, and human tissues through inhalation, diet and manual handling, which may affect the growth, development, and survival of the organisms (Ali et al. 2019, Asati et al. 2016, Jaishankar et al. 2014). Copper (Cu), manganese (Mn), lead (Pb), cadmium (Cd), mercury ( $\mathrm{Hg})$, nickel (Ni), cobalt (Co), iron (Fe), zinc ( $\mathrm{Zn}$ ), chromium (Cr), iron $(\mathrm{Fe})$, arsenic $(\mathrm{As})$, silver $(\mathrm{Ag})$ and the platinum $(\mathrm{Pt})$ as examples of naturally abundant heavy metals. These heavy metals except $\mathrm{Pb}$, $\mathrm{Cd}$ and $\mathrm{Hg}$ may be essential in minute quantities by organisms, excessive amounts of these elements can become harmful to organisms (Briffa et al. 2020, Raskin et al. 1994).

Whereas, some of heavy metals such as $\mathrm{Fe}, \mathrm{Mn}$ and $\mathrm{Zn}$ were considered as essential micronutrients elements for plants, animals and other living organisms (Gomes et al. 2021, Rengel 2015, Singh \&Schulze 2015); But toxic effect s could be monitored upon the uptake in excess to the requirements of plant, in such case it will have a negative effect on the nutritional equilibrium in soil (Djingova \&Kuleff 2000, Reeves 2000, Wintz et al. 2002). Iron (Fe) is primarily involved in the process of photosynthesis in plants. The availability of micronutrients to plant roots is affected by soil pH, with iron being more readily available in soil with a low pH (Becker \&Asch 2005, Morrissey \&Guerinot 2009, Neina 2019, Rout \&Sahoo 2015). Moreover, both of iron (Fe) and manganese (Mn) are essential micronutrients for plant growth and development, but they frequently compete for absorption because an abundance of one of these micronutrients makes the other less available plant roots. In addition, iron is existing as a basic component in the composition of heme proteins such cytochromes, catalase, peroxidase, and leghemoglobin, as well as iron Sulphur proteins like ferredoxin, aconitase, and superoxide dismutase (SOD) (Gautam \&Dubey 2018). Whereas, zinc (Zn) aids in the production of chlorophyll in plants. When the soil is lacking in zinc, the leaves darken and plant growth is impeded (Hafeez et al. 2013). In addition, manganese (Mn) is a vital plant mineral nutrient that is involved in a variety of physiological activities, including photosynthesis. Manganese shortage is a common problem in sandy soils, organic soils with a pH above 6, and tropical soils that are highly weathered. Mn is easily transferred from root to shoot via the transpiration stream, but it is not easily remobilized to other organs via phloem once it reaches the leaves (Loneragan 1988).

Engineered nanomaterials have received great attention due to their unique properties, which provide an opportunity to be used in several applications especially in agricultural sector (Chemingui et al. 2019, Chhipa 2019, Naderi \&Abedi 2012, Usman et al. 2020).

Nanomaterials increase crop productivity and efficiently regulate micronutrients delivery to plants and targeted sites, ensuring that agrochemicals are used as little as possible (Mishra \&Khare 2021). In addition, increase crop yield by increasing fertilizer nutrient availability in soil and nutrient uptake by plants (Sarkar et al. 2021). Nano-fertilizers or nano-encapsulated nutrients may have qualities that are beneficial to crops, such as on-demand release of nutrients, and controlled release of chemical fertilizers to regulate plant growth and accelerate target activity (DeRosa et al. 2010, Nair et al. 2010, Sampathkumar et al. 2020, Zhang et al. 2021)

Phytoremediation is a renewable technology that restores contaminated soil and water sources by using either natural or genetically modified plant species. In various review articles examining the principles, types, and mechanisms of the phytoremediation process, the 
advantages of low cost, environmental friendliness, and safety are highlighted (Al-Khazan \&Al-Zlabani, Arthur et al. 2005, Parmar \&Singh 2015). Poplars are frequently used in phytoremediation because of their rapid growth, adaptability, a well-developed root system that reaches underground waters, and the ability to transpire large amounts of water (Aitchison et al. 2000). But they can't compete with hyper-accumulators in the heavy metal accumulation, but they didn't have a significant advantage in biomass production (Laghlimi et al. 2015, Liu et al. 2013, Pulford \&Watson 2003) and a relatively high amount of extracted metal per plant (Di Lonardo et al. 2011). White poplars, in particular, are interesting due to their high tolerance to arid conditions and their use in horticulture and landscaping, especially genotypes with a pyramidal tree shape (Kovačević et al. 2010).

The in-vitro culture of tree species offers a rapid instrument to produce the clonal planting stock, but it may also facilitate studies on the effects of elevated levels of heavy metals on plant performance and the selection of metal-tolerant genotypes (Di Lonardo et al. 2011). Castiglione et al. observed that the in vitro model was a sensitive and reliable system for studying heavy metal stress responses in their study of white poplars based on developmental and molecular data (Castiglione et al. 2007). This is significant given the difficulties of experimenting on large, long-lived organisms. The tolerance of white poplars to heavy metals, including lead, was tested under conditions, and genotype differences were encountered (Bojarczuk 2004, Kališová-Špirochová et al. 2003, Katanic et al. 2008).

Herein, we aimed to investigate the in-vitro assay of Populus alba upon the treatment with nano-oxide particles forms of each of $\mathrm{Fe}, \mathrm{Mn}$ and $\mathrm{Zn}$ (e.g., $\mathrm{Fe}_{2} \mathrm{O}_{3}, \mathrm{ZnO}$ and $\mathrm{Mn}_{2} \mathrm{O}_{3} \mathrm{NPs}$ ) as micronutrients through evaluation of growth parameters and photosynthetic index. In addition, testing their genetic stability using RAPD-PCR techniques. The obtained results will help us in tracking of phytoremediation activity of Populus alba (P. alba) via the tolerance of plant to grow in heavy metal contamination.

\section{Materials And Methods}

\subsection{Materials}

Zinc sulfate heptahydrate $\left(\mathrm{ZnSO}_{4} \cdot 7 \mathrm{H}_{2} \mathrm{O}, 99 \%\right)$, Ferrous sulphate hepta-hydrate $\left(\mathrm{Fe}_{2} \mathrm{SO}_{4} \cdot 7 \mathrm{H}_{2} \mathrm{O}, 98 \%\right)$, manganese sulphate $\left(\mathrm{MnSO}_{4,99 \%}\right)$ and sodium hydroxide $(\mathrm{NaOH}, 98 \%)$, were used in the experiments without any further purification. All the chemicals used were of analytical reagent grade obtained from LOBA chemicals and deionized water is used for the preparation of solutions.

\subsection{Preparation of Nano-metal oxides for in-vitro phytoremediation 2.2.1. Preparation of Iron Oxide Nanoparticles}

Briefly, Iron oxide ( $\mathrm{Fe}_{2} \mathrm{O}_{3}-\mathrm{NPs}$ ) nanoparticles were synthesized via co-precipitation method as previously reported by Yang et al. (Yang et al. 2014) with slight modification. Briefly; iron salt precursor was mixed with deionized water under vigorous stirring for 10 min to ensure that all the ferrous salt was dissolved with a concentration of $(1 \mathrm{M})$. In a $100 \mathrm{ml}$ beaker, sodium hydroxide was prepared with concentration of $(2 \mathrm{M})$. In this protocol, the sodium hydroxide solution was added to the iron solution drop-wise under constant stirring. After the complete addition of hydroxide solution, the reaction mixture was left for $2 \mathrm{~h}$. Finally, the black solution was washed repeatedly with deionized water to remove the excess hydroxides keeping the $\mathrm{pH}$ of the slurry around 7 and dried at $50^{\circ} \mathrm{C}$ overnight.

\subsubsection{Synthesis of Zinc Oxide Nanoparticles}

Zinc oxide nanoparticles were prepared via co- precipitation method according reported previously (Koutu et al. 2016, Kumar et al. 2013). Typically, sodium hydroxide aqueous solution was drop-wisely added with a slow rate to an aqueous solution of zinc sulfate with a molar ratio of 1:2 under vigorous stirring for $12 \mathrm{~h}$. The obtained precipitate was centrifuged and washed with deionized water several time till $\mathrm{pH}(6.5-7)$. The resultant precipitate was dried in an oven at $80^{\circ} \mathrm{C}$ and grinded to fine powder using a mortar. The powder obtained was calcined at $300^{\circ} \mathrm{C}$ for $2 \mathrm{~h}$.

\subsubsection{Synthesis of Manganese dioxide Nanoparticles:}

Manganese oxide nanoparticles have been prepared using co-precipitation as reported by Kumar et al. (Kumar et al. 2013) and Cherian et al. (Cherian et al. 2016). Briefly; freshly prepared $100 \mathrm{ml}$ aqueous solution of $2 \mathrm{M} \mathrm{NaOH}$ was added drop by drop to $100 \mathrm{ml}$ of $2 \mathrm{M}$ $\mathrm{MnSO}_{4}$. The solution was stirred continuously at $60^{\circ} \mathrm{C}$ for $2 \mathrm{~h}$ to precipitate the nanoparticles. The precipitate was then separated from the reaction mixture and washed several times with deionized water and dried in hot air oven at $100^{\circ} \mathrm{C}$ overnight.

\subsection{Characterization:}


The morphological structure of the as-prepared nano-metal oxides particles (e.g.; $\mathrm{Fe}_{2} \mathrm{O}_{3}$, $\mathrm{ZnO}$ and $\mathrm{Mn}_{2} \mathrm{O}_{3}-\mathrm{NPs}$ ) using Transmission Electron Microscope (TEM) JOEL-JEM 2100 to investigate the micrograph of obtained samples under operating voltage $200 \mathrm{kV}$, and Xray diffraction (XRD) measurements have been carried out using a Bruker D8 advance X-Ray Powder Diffractometer operating with a Cu target with $\mathrm{Ka} 1=1.54060 \AA, \mathrm{Ka} 2=1.5444 \AA$, with $2 \theta$ step $4^{\circ}$ and recorded at the range from $20^{\circ}$ to $80^{\circ}$. In addition; the size distribution of as-prepared nanoparticles was measured by Malvern zeta-sizer Nano ZS instrument with He/Ne laser (633 nm) at an angle of $173^{\circ}$ collecting backscatter optics. Finally; Fourier-transform infrared spectroscopy (FT-IR) has been used for exploring the chemical groups functionalized their surfaces.

\subsection{Plant Materials and Culture with nano-metal oxide}

Explants of Populus alba nodal segments were cultured and acclimatized on Murashige and Skoog medium (MS medium) as reported by Ahmed and co-workers (Hewidy et al. 2019). Each nano-metal oxides of the heavy element (i.e., Fe, Zn, Mn) that used as micronutrients were prepared in three different concentrations of (i.e., 20, $40,60 \mathrm{mg} / \mathrm{L}$ ). These different concentrations were inoculated in MS jars separately. The nodal segments of Populus alba were cultured in these jars comparing to control. After that, these cultures were incubated at $25^{\circ} \mathrm{C}$ for 4 weeks, then the measurements were estimated.

\subsection{Morphological Measurements}

The following seven morphological biometric parameters were measured for all these treatments: plantlet fresh weight, shoot length, shoot number, root length, leaf number, number of roots and rooting percentage.

\subsection{Chlorophyll Estimation}

Chlorophyll index was measured using OPTI-SCIENCES (CCM-200 plus) to indicate the photosynthesis rate in response to the different nano-heavy metals uptake.

\subsection{Estimation of Nano-metal oxides particles in Populus Tissues}

The nano-metal oxides particles ( $\mathrm{Fe}, \mathrm{Zn}$ and $\mathrm{Mn}$ ) were estimated in the $P$. alba tissues. The plant tissues were dried in oven at $80^{\circ} \mathrm{C}$ for $48 \mathrm{~h}$ then grounded well to powder and fixed known weight of samples $(0.03 \mathrm{~g})$ was digested with $5 \mathrm{~mL} \mathrm{HNO}_{3}$ at $110^{\circ} \mathrm{C}$ for $2 \mathrm{~h}$, cooled, added $1 \mathrm{~mL}$ of $\mathrm{H}_{2} \mathrm{O}_{2}$ and boiled for $1 \mathrm{~h}$. The clear digests were diluted to $50 \mathrm{~mL}$ with triple-deionized water (Shirani Bidabadi 2020). The concentrations of the different nano-heavy metals were estimated using Agilent 4200 MP-AES according to manufacture instructions.

\subsection{DNA Isolation and RAPD-PCR Bioassay}

The genomic DNA of $P$. alba different treatments was isolated according to Lu et al. (Lu et al. 2011). RAPD-PCR bioassay was applied using 10 primers, only 6 of them gave clear reproducible bands. The reaction mixture was prepared as follow: $12.5 \mu$ of master mix (Bioline ${ }^{\circledR}$ ), $1.5 \mu \mathrm{l}$ of both forward and reverse primers, $2 \mu \mathrm{l}$ genomic DNA and diluted to $25 \mu \mathrm{l}$ by adding $7.5 \mu \mathrm{l}$ sterile ddH $\mathrm{H}_{2} \mathrm{O}$. The reaction program was performed in thermocycler Biometra ${ }^{\circledR}$ (Germany). The Amplification process was performed using 35 cycles of: 30 sec at $95^{\circ} \mathrm{C} ; 30 \mathrm{sec}$ at the melting temperature (Tm) of the specific primer (Table 1$)$, and $1 \mathrm{~min}$ at $72^{\circ} \mathrm{C}$. The resulted PCR products were screened on a $1.4 \%$ (wt/vol) agarose gel (Agagel Mini; Biometra $\left.{ }^{\circledR}\right)$. Gel images were analysis with BioRad Quantity One (4.6.2) software using the method described by Williamson and Campbell (Campbell 1997) and Bio-Rad Laboratories (2005).

Table 1

Primer Data analysis of RAPD-PCR bioassay with Populus treatments.

\begin{tabular}{|lllllll|}
\hline Name & Seq & $T_{\mathbf{m}}$ & Total no. of bands & Polymorphic bands & Polymorphism \% & Size range bp \\
\hline Deca-12 & 5'-CTTGCCCACG-3' & 38.5 & 4 & 0 & 0 & $509-792$ \\
\hline Deca-13 & 5'-GTGGCAAGCC-3' & 39 & 3 & 3 & 100 & $215-678$ \\
\hline Deca-11 & 5'-ATCGGCTGGG-3' & 39.3 & 5 & 1 & 20 & $135-559$ \\
\hline Deca-7 & 5'- CCGCCCGGAT-3' & 45 & 2 & 0 & 0 & $418-707$ \\
\hline Deca-4 & 5'-CGTTGGCCCG-3' & 44 & 4 & 1 & 25 & $194-566$ \\
\hline Deca-10 & 5'-AGCCGGCCTT-3' & 43.1 & 5 & 3 & 60 & $121-730$ \\
\hline & Total & 23 & 8 & 34.17 & \\
\hline
\end{tabular}

\subsection{Statistical Analysis}


The statistical analysis of morphology, physiology and nano-heavy metals data in this work was performed using Minitab 19 with the following analysis: descriptive analysis, general linear model, grouping by Tukey pairwise comparison, correlation. A combined phylogenetic tree and correlation PCA blot was obtained from all data using Community Analysis Package (CAP software).

\section{Results}

\subsection{Synthesis and characterization of nano-metal oxides particles}

Heavy metal-based oxides nanoparticles micronutrients including $\mathrm{Fe}_{2} \mathrm{O}_{3}, \mathrm{ZnO}$ and $\mathrm{Mn}_{2} \mathrm{O}_{3}$ were prepared via co-precipitation methods as

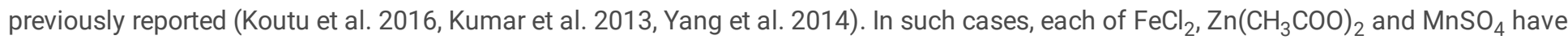
been used as metal precursors, which chemically hydrolysis in alkali medium forming metal-hydroxide. Then the metal-hydroxide precipitate was treated thermally to form metal-oxide nanoparticles. The formation mechanism for each of $\mathrm{Fe}_{2} \mathrm{O}_{3}, \mathrm{ZnO}$ and $\mathrm{MnO}_{2} \mathrm{NPs}$ was demonstrated as follow;

$$
\begin{aligned}
& M-O-R+\mathrm{H}_{2} \mathrm{O} \rightarrow \mathrm{M}-\mathrm{OH}+\mathrm{R}-\mathrm{OH} \\
& M-\mathrm{OH}+\mathrm{M}-\mathrm{OH} \rightarrow \boldsymbol{M}-\boldsymbol{O}-\boldsymbol{M}+\mathrm{H}_{2} \mathrm{O}
\end{aligned}
$$

The morphological structure has been confirmed via TEM and XRD measurements as shown in Figs. 1 and 2, respectively. TEM micrographs showed that $\mathrm{Fe}_{2} \mathrm{O}_{3} \mathrm{NPs}$ are quasi-spherical and relatively narrow size distribution. The average particle size was in a range of $35 \pm 5 \mathrm{~nm}$ (Figs. $1 \mathrm{a}$ and 1b). While in case of as-prepared ZnO NPs, the average particle size was in the range of $30 \pm 5 \mathrm{~nm}$ with quasispherical shape (See Figs. $1 \mathrm{c}$ and 1d). Finally, the average particle size of $\mathrm{Mn}_{2} \mathrm{O}_{3}$ was in range of $40 \pm 10 \mathrm{~nm}$, with agglomerated spherical nanoparticulate in vesicles (See Figs. 1e and 1f).

Furthermore, XRD measurements were carried out to investigate the crystallographic structure of as-prepared metal-based oxides nanoparticles of $\mathrm{ZnO}, \mathrm{Fe}_{2} \mathrm{O}_{3}$ and $\mathrm{Mn}_{2} \mathrm{O}_{3}$-NPs, as shown in Fig. 2. XRD patterns of $\mathrm{ZnO}$ NPs indicated to formation of hexagonal structure of $\mathrm{ZnO}$ nanoparticles (See Fig. 2a), where three strongest lines has been obtained at $31.28^{\circ}, 33.948^{\circ}$ and $35.81^{\circ}$ due to the (100), (002) and (101) crystallographic plans of hexagonal structure of ZnO NPs (i.e., Zincite), as reported by ICCD-PDF no. 00-005-0664. In addition, existence of five diffraction reflections at $47.14^{\circ}, 55.93^{\circ}, 62.33^{\circ}, 67.47^{\circ}$ and $71.92^{\circ}$ due to (102), (110), (103), (112) and (004) reflection plans for hexagonal crystallographic structure of ZnO NPs. Whereas Fig. $2 b$ showed the XRD patterns of as-prepared hematite nanoparticles (i.e., $\mathrm{Fe}_{2} \mathrm{O}_{3} \mathrm{NPs}$ ). Two strongest lines observed at $32.6^{\circ}$ and $35.16^{\circ}$ due to (104) and (110) reflection plans of rhombohedral crystallographic structure of hematite nanoparticles (i.e., $\mathrm{Fe}_{2} \mathrm{O}_{3} \mathrm{NPs}$, See Fig. 2b). Moreover, another five diffraction patterns monitored at $40.35^{\circ}, 42.95^{\circ}, 48.59^{\circ}, 53.84^{\circ}$, and $63.48^{\circ}$ due to (113), (202), (024), (116) and (300) reflection plans for rhombohedral crystallographic structure of $\mathrm{Fe}_{2} \mathrm{O}_{3} \mathrm{NPs}$, respectively (See Fig. 2b). While XRD patterns of manganese oxide nanoparticles revealed a mixture of crystallographic reflection plans for both of $\mathrm{Mn}$ (III) and $\mathrm{Mn}$ (IV) oxides nanoparticles (i.e., $\mathrm{Mn}_{2} \mathrm{O}_{3}, \mathrm{and} \mathrm{Mn}_{3} \mathrm{O}_{4} \mathrm{NPs}$ ), respectively. As depicted in Fig. 2c, Mn (III) oxide nanoparticles $\left(\mathrm{Mn}_{2} \mathrm{O}_{3} \mathrm{NPs}\right)$ exhibited the dominant crystallographic structure with cubic structure (See Fig. 2c). Where the two strongest lines of $\mathrm{Mn}_{2} \mathrm{O}_{3}$ were observed at $32.41^{\circ}$ and $54.64^{\circ}$ corresponding to (222) and (440) reflection plans for the cubic structure of $\mathrm{Mn}_{2} \mathrm{O}_{3} \mathrm{NPs}$. These diffraction patterns were accompanied with another four diffraction patterns that recorded at $35.56^{\circ}, 40.1^{\circ}, 48.89^{\circ}$ and $65.12^{\circ}$ corresponding to (321), (441), (431) and (622) reflection plans of $\mathrm{Mn}_{2} \mathrm{O}_{3} \mathrm{NPs}$. Furthermore, the minor phase that corresponded to tetragonal crystallographic structure $\mathrm{Mn}_{3} \mathrm{O}_{4} \mathrm{NPs}$, which exhibits diffraction patterns at $22.62^{\circ}, 29.17^{\circ}, 37.66^{\circ}, 44.55^{\circ}$ and $59.53^{\circ}$ for (200), (202), (213), (204), and (404) reflection plans, respectively (See Fig. 2c).

In addition, the colloidal properties based on DLS and zeta potential measurements for $\mathrm{Fe}_{2} \mathrm{O}_{3}, \mathrm{ZnO}$ and $\mathrm{Mn}_{2} \mathrm{O}_{3}$ nanoparticles were investigated as shown in Fig. 3. It's clear that the hydrodynamic particle size of for as-prepared nanoparticles is remarkably increased, which is in agreement with their agglomeration presented in TEM micrographs as shown in Fig.1. This is due to their hydrophilicity nature. Furthermore, the strength of the steric forces of the functional groups on the surface of nanoparticles, as well as a steric interaction caused by the formation of a layer of water around the material (Marimón-Bolívar \&González 2018). In this regard; $\mathrm{Fe}_{2} \mathrm{O}_{3}$ nanoparticles was about $232 \pm \mathbf{2 9 . 2 4} \mathrm{nm}$ (See Fig. 3a and Table 2). In addition, $\mathrm{Fe}_{2} \mathrm{O}_{3}$ nanoparticles exhibit a good dispersion in water, where the polydispersity index (Pdl) is about 0.586 . Moreover, Zeta potential ( () of $\mathrm{Fe}_{2} \mathrm{O}_{3}$ nanoparticles was about $-6.96 \mathrm{mV}$. While, the hydrodynamic particle size of $\mathrm{Mn}_{2} \mathrm{O}_{3}$ nanoparticles was smaller than $\mathrm{Fe}_{2} \mathrm{O}_{3}$ about $201 \pm 143 \mathrm{~nm}$. In addition, $\mathrm{Mn}_{2} \mathrm{O}_{3}$ nanoparticles exhibit a good dispersion in water, where the polydispersity index ( $\mathrm{Pdl}$ ) is about $\mathbf{0 . 5 8 5}$ (See Fig. $\mathbf{3 c}$ and Table 2). Moreover, Zeta potential (『) of $\mathrm{Mn}_{2} \mathrm{O}_{3}$ nanoparticles exhibits positively charged $+1.39 \mathrm{mV}$. Finally; ZnO NPs exhibited a smaller $\mathrm{H}_{\mathrm{D}}$ than $\mathrm{Fe}_{2} \mathrm{O}_{3}$ and $\mathrm{Mn}_{2} \mathrm{O}_{3} \mathrm{NPs}$, 
respectively See (Fig. 3e and Table 2). The hydrodynamic particle size of ZnO NPs was $129.1 \pm 16.6 \mathrm{~nm}$, and the polydispersity index $(\mathrm{Pdl})$ is about $\mathbf{0 . 7 9 7}$ indicating to their fair dispersion in water. Moreover, Zeta potential ( $\mathbb{\text { }}$ ) of ZnO nanoparticles exhibits more electronegative was about $-14 \mathrm{mV}$.

\begin{tabular}{|c|c|c|c|}
\hline \multirow[t]{2}{*}{ Sample } & \multicolumn{2}{|c|}{ Dynamic Light Scattering (DLS) } & \multirow[t]{2}{*}{ Zeta potential $(\mathbb{\nabla}, \mathrm{mV})$} \\
\hline & $\begin{array}{l}\text { Hydrodynamic Diameter } \\
\left(\mathrm{H}_{\mathrm{D}}, \mathrm{nm}\right)\end{array}$ & Polydispersity Index (Pdl) & \\
\hline $\mathrm{Fe}_{2} \mathrm{O}_{3}-\mathrm{NPs}$ & $232 \pm 29.24$ & 0.586 & -6.96 \\
\hline $\mathrm{Mn}_{2} \mathrm{O}_{3}$-NPs & $201 \pm 143$ & 0.585 & +1.39 \\
\hline ZnO-NPs & $129.1 \pm 16.6$ & 0.797 & -14 \\
\hline
\end{tabular}

Finally, the surface properties of the as-prepared metal-based oxides nanoparticles via exploring their FT-IR spectra, as shown in Fig. 4. FT-IR spectrum of $\mathrm{Fe}_{2} \mathrm{O}_{3}$ NPs exhibited several absorption bands as follows (See Fig. 4a); considering the broadband for the $-\mathrm{OH}$ stretching vibration in the range of 3550-3100 $\mathrm{cm}^{-1}$. Also, the absorption bands at 1640,1430 , and $1421 \mathrm{~cm}^{-1}$ are associated with stretching vibration of the $-\mathrm{C}=\mathrm{O}$ group and the bending vibration of adsorbed water, $-\mathrm{CH}$ group. The absorption band at $2890 \mathrm{~cm}^{-1}$ is attributed to the stretching vibration of the aliphatic saturated $-\mathrm{CH}$ group. The peak for $\mathrm{C}-\mathrm{H}$ and $\mathrm{C}-\mathrm{O}$ bending vibrations are around 1157 and $1112 \mathrm{~cm}^{-1}$, respectively. Furthermore, the bending vibration of the -C-O group is indicated by the absorption peak at $1060 \mathrm{~cm}^{-1}$. While in the case of ZnO-NPs; the broadband for the $-\mathrm{OH}$ stretching vibration is in the range of $3420 \mathrm{~cm}^{-1}$. Also, the absorption bands at 1640 , 1430 , and $1421 \mathrm{~cm}^{-1}$ are associated with stretching vibration of the $-\mathrm{C}=\mathrm{O}$ group and the bending vibration of adsorbed water, $-\mathrm{CH}$ group. The absorption band at $2925 \mathrm{~cm}^{-1}$ is attributed to the stretching vibration of the aliphatic saturated $-\mathrm{CH}$ group. The peak for $\mathrm{C}-\mathrm{H}$ and $\mathrm{C}-\mathrm{O}$ bending vibrations are around 1157 and $1112 \mathrm{~cm}^{-1}$, respectively. Furthermore, the bending vibration of the -C-O group is indicated by the absorption peak at $1060 \mathrm{~cm}^{-1}$. The absorption band at $895 \mathrm{~cm}^{-1}$ is attributed to the strong bending vibration of $-\mathrm{C}=\mathrm{C}$ - in vinylidene (See Fig. 4b). Finally, the FT-IR spectrum for the as-prepared $\mathrm{Mn}_{2} \mathrm{O}_{3}$ NPs depicted in Fig. 4c demonstrated that the broadband for the $-\mathrm{OH}$ stretching vibration is in the range of $3420 \mathrm{~cm}^{-1}$. Also, the absorption bands at 1640,1430 , and $1421 \mathrm{~cm}^{-1}$ are associated with stretching vibration of the $-\mathrm{C}=0$ group and the bending vibration of adsorbed water, $-\mathrm{CH}$ group. The absorption band at $2925 \mathrm{~cm}^{-1}$ is attributed to the stretching vibration of the aliphatic saturated $-\mathrm{CH}$ group. The peak for $\mathrm{C}-\mathrm{H}$ and $\mathrm{C}-\mathrm{O}$ bending vibrations are around 1157 and $1112 \mathrm{~cm}^{-}$ ${ }^{1}$, respectively. Furthermore, the bending vibration of the $-\mathrm{C}-0$ group is indicated by the absorption peak at $1060 \mathrm{~cm}^{-1}$. The absorption band at $895 \mathrm{~cm}^{-1}$ is attributed to the strong bending vibration of $-\mathrm{C}=\mathrm{C}$ - in vinylidene (See Fig. $4 \mathrm{c}$ ).

\subsection{Morphological Parameters and Chlorophyll Content}

Seven morphological parameters included with a fixed rooting percentage of $(100 \%)$ have been investigated for all treatments. In this regard, the other six parameters varied and have significant differences upon their treatment with 3 different level of doses from metal oxide nanoparticles compared to control (Table 3). The chlorophyll index reflecting photosynthesis process varied but has no significant difference (Table 3). Moreover, the correlation relationship among all the parameters (Table 4) illustrating that nearly most of the parameter's range has positively affected each other, except rooting percentage which negatively affected the other parameters in response to metal oxide nanoparticles treatments. 
Table 3 Means of morphological and physiological parameters of $P$. alba in response to nano-heavy metals using Tukey pairwise comparison

\begin{tabular}{|c|c|c|c|c|c|c|c|c|c|c|c|}
\hline \multirow[t]{2}{*}{ Treatment } & \multicolumn{3}{|c|}{$\mathrm{Fe}_{2} \mathrm{O}_{3} \mathrm{NPs}(\mathrm{mg} / \mathrm{L})$} & \multicolumn{3}{|c|}{ ZnO NPs (mg/L) } & \multicolumn{3}{|c|}{$\mathrm{Mn}_{2} \mathrm{O}_{3} \mathrm{NPs}(\mathrm{mg} / \mathrm{L})$} & \multirow[t]{2}{*}{ Control } & \multirow[t]{2}{*}{$\begin{array}{l}P \text { - } \\
\text { value }\end{array}$} \\
\hline & 20 & 40 & 60 & 20 & 40 & 60 & 20 & 40 & 60 & & \\
\hline $\begin{array}{l}\text { Fresh wt. } \\
\text { ' } g \text { ' }\end{array}$ & $0.210^{d}$ & $0.191^{\mathrm{e}}$ & $0.178^{g}$ & $0.145^{h}$ & $0.135^{i}$ & $0.185^{f}$ & $0.223^{c}$ & $0.261^{b}$ & $0.292^{\mathrm{a}}$ & $0.189^{\text {ef }}$ & 0.00 \\
\hline $\begin{array}{l}\text { Shoot } \\
\text { length 'cm' }\end{array}$ & $7.033^{b}$ & $6.766^{\mathrm{bcd}}$ & $6.366^{e}$ & $5.566^{\mathrm{g}}$ & $6.033^{f}$ & $6.566^{\text {cde }}$ & $7.033^{b}$ & $6.533^{\mathrm{de}}$ & $7.966^{\mathrm{a}}$ & $6.833^{b c}$ & 0.00 \\
\hline $\begin{array}{l}\text { Shoot } \\
\text { number }\end{array}$ & $1.000^{\mathrm{b}}$ & $1.000^{\mathrm{b}}$ & $1.000^{\mathrm{b}}$ & $1.000^{b}$ & $1.000^{\mathrm{b}}$ & $1.000^{\mathrm{b}}$ & $2.000^{\mathrm{a}}$ & $2.000^{\mathrm{a}}$ & $2.000^{\mathrm{a}}$ & $1.000^{b}$ & 0.10 \\
\hline $\begin{array}{l}\text { Leaf } \\
\text { number }\end{array}$ & $8.333^{c}$ & $9.000^{\mathrm{C}}$ & $10.00^{c}$ & $8.667^{c}$ & $9.000^{c}$ & $8.667^{c}$ & $14.33^{a b}$ & $15.66^{a}$ & $12.33^{b}$ & $9.000^{c}$ & 0.00 \\
\hline $\begin{array}{l}\text { Root } \\
\text { length 'cm' }\end{array}$ & $4.133^{\text {cde }}$ & $4.433^{c}$ & $4.366^{\text {cde }}$ & $5.067^{b}$ & $4.067^{\mathrm{de}}$ & $4.033^{e}$ & $8.033^{a}$ & $4.400^{\mathrm{cd}}$ & $4.067^{\mathrm{de}}$ & $5.133^{b}$ & 0.00 \\
\hline $\begin{array}{l}\text { Root } \\
\text { number }\end{array}$ & $5.333^{d}$ & $7.000^{\mathrm{bc}}$ & $7.000^{\mathrm{bc}}$ & $7.667^{\mathrm{ab}}$ & $6.000^{\mathrm{cd}}$ & $8.667^{a}$ & $3.000^{e}$ & $5.000^{d}$ & $5.000^{d}$ & $5.667^{c d}$ & 0.00 \\
\hline Chl. index & $9.300^{\mathrm{a}}$ & $10.900^{a}$ & $7.700^{\mathrm{a}}$ & $3.333^{a}$ & $3.830^{\mathrm{a}}$ & $4.330^{\mathrm{a}}$ & $10.60^{a}$ & $5.130^{\mathrm{a}}$ & $5.830^{a}$ & $5.630^{a}$ & 0.55 \\
\hline
\end{tabular}

Table 4 Correlation among Populus alba different measured parameters in response to non-heavy metals treatments

\begin{tabular}{|c|c|c|c|c|c|c|}
\hline & Fresh wt. & Shoot length & shoot.no & leaf.no & Root length & root.no \\
\hline Shoot length & 0.818 & & & & & \\
\hline shoot.no & 0.827 & 0.540 & & & & \\
\hline leaf.no & 0.697 & 0.343 & 0.917 & & & \\
\hline Root length & 0.060 & 0.068 & 0.412 & 0.432 & & \\
\hline root.no & -0.534 & -0.492 & -0.704 & -0.634 & -0.583 & \\
\hline Chlorophyll & 0.131 & 0.170 & 0.092 & 0.031 & 0.198 & -0.237 \\
\hline
\end{tabular}

\subsection{Estimation of Metal oxide nanoparticles uptake in Populus alba}

Populus alba treated with different nano-metal oxide. The metals uptake by $P$. alba was nearly the same with no significant differences (Table 5). This confirms the equivalent nano heavy metals-based oxides uptake by plants. Hence, the estimated morphological and chlorophyll parameters is related to the type of nano- metal oxides beside the concentration.

Table 5 Concentration of different nano-heavy metals uptake in $P$. alba in vitro culture

\begin{tabular}{|c|c|c|c|c|c|c|c|c|c|c|c|}
\hline \multirow[t]{2}{*}{ Treatment } & \multicolumn{3}{|c|}{$\mathrm{Fe}_{2} \mathrm{O}_{3} \mathrm{NPs}(\mathrm{mg} / \mathrm{L})$} & \multicolumn{3}{|c|}{ ZnO NPs (mg/L) } & \multicolumn{3}{|c|}{$\mathrm{Mn}_{2} \mathrm{O}_{3} \mathrm{NPs}(\mathrm{mg} / \mathrm{L})$} & \multirow[t]{2}{*}{ Control } & \multirow[t]{2}{*}{$P$-value } \\
\hline & 20 & 40 & 60 & 20 & 40 & 60 & 20 & 40 & 60 & & \\
\hline Metal conc. 'ppm' & $0.297^{a}$ & $0.407^{a}$ & $0.377^{a}$ & $0.557^{a}$ & $0.637^{a}$ & $0.787^{a}$ & $0.430^{\mathrm{a}}$ & $0.467^{a}$ & $0.750^{\mathrm{a}}$ & $0.410^{\mathrm{a}}$ & $0.138^{a}$ \\
\hline
\end{tabular}

\subsection{DNA Isolation and RAPD-PCR Bioassay}

Genetic stability of Populus alba treatments by heavy metal-based oxides nanoparticles micronutrients have a great practical utility and commercial implications. In this study, we estimated the fingerprinting profiles of the regenerated culture by RAPD to confirm if the plantlets were genetically stable or not. A total of 10 random decamer-RAPD primers were tested for initial screening, among them only 6 primers gave clear and reproducible bands. The number of polymorphic bands ranged from 2 bands with Deca-7 primer, to 5 polymorphic bands with both Deca-11 and Deca-10 primers (Table 1). These 6 primers produced a total number of 23 bands with 8 
polymorphic bands resulted in a total polymorphism percentage of $34.17 \%$ (See Fig. 5). The total molecular weights of all bands were ranged from 121-792 bp. Figure 6 showed a total phylogenetic tree resulted from all the combined morphological parameters, chlorophyll index and genetic variation. Figure 7 showed principal component analysis (PCA) blot which showed the correlation among the different nano-heavy metals effect on $P$. alba plant. The graph illustrated that the responses to nano-Mn concentrations are separated away, where control, nano-Fe and nano-Zn are grouped to each other.

\section{Discussion}

Recently, looking for economic and eco-friendly techniques for soil heavy metals remediation instead of conventionally used physicochemical techniques became urgent need. This is due to the biological techniques are based on phytoremediation not have any side effects on soil ecosystem; in addition, they are economically in contrast to other traditionally used techniques (Al-Khazan \&AlZlabani , Gómez-Sagasti et al. 2012). The effect of Populus alba uptake to the nano-heavy metals micronutrients varied and reflected on morphological and chlorophyll parameters. As, some parameters were enhanced with exposure to heavy metal-based oxides nanoparticles micronutrients, where the others were inhibited comparing to control. The toxic effect of most heavy metals is caused by their bonding to -SH protein groups leading to the inhibition of enzyme activity and compromising their structure. They also substitute essential elements in biomolecules causing their deficiency (Van Assche \&Clijsters 1990). High concentrations of metal ions in the soil limit the assimilation of important micro- and macronutrients by plants (Oleksyn et al. 1996).

The acclimatization of $P$. alba culture was performed by Ahmed et al. (Hewidy et al. 2019) and El-Sayed et al. (El-Sayed et al. 2019) to obtain the best growth conditions. Gomes and co-workers explored the morphological, anatomical parameters and chlorophyll content for affected vegetation area surrounding the mining company produced heavy metals such as $\mathrm{Zn}, \mathrm{Cd}$ and $\mathrm{Pb}$ (Gomes et al. 2011). Moreover, Sadak and Bakry suggested the using of $\mathrm{ZnO}$ as an example of metal oxide based nanomaterials than bulk form in the treatment of plant (Sadak \&Bakry 2020). In such study; ZnO-NPs exhibited a good effect and improved each of biochemical, growth aspects, and consequent biomass yield.

Our findings were in agreement with previous reports by Atteya et al. (Atteya et al. 2018) and Gheith et al. (Gheith et al. 2018), respectively. In their studies, a remarkable increase in the biomass yield and plant growth parameters observed upon the treatment of both of jojoba and maize with Zn precursors (Atteya et al. 2018, Gheith et al. 2018). However, Prasad and co-worker proved that ZnO-NPs has a remarkable effect on the enhancement of peanut plant growth, and biomass yield higher than ordinary $\mathrm{Zn}$ precursor such as $\mathrm{ZnSO}_{4}$ at lower concentration. This is attributed to high adsorption of $\mathrm{ZnO}-\mathrm{NPs}$ in the plant based on their smaller size than $\mathrm{ZnSO}_{4}$ (Prasad et al. 2012). Finally, Tawfik and co-worker reported that a significant increase in the growth parameters of Atriplex halimus upon treatment with ZnO-NPs in saline environments (Tawfik et al. 2017).

\section{Conclusion}

This study evaluated the in vitro propagation ability, photosynthetic pigments contents and genetic variation of $P$. alba under pollution with heavy metal-based oxides nanoparticles causes variation in growth due to changes in their physiological and biochemical activities, which is especially true when the heavy metal involved plays no beneficial role in plant growth and development. The genetic variation in DNA content of polluted $P$. alba individuals, adapt the plant to tolerate and adapt to nano-heavy metals contamination.

\section{Declarations}

\section{Ethical Approval / Consent to Participate /}

Not applicable

\section{Consent to Publications}

All authors accepted the publication of the manuscript in the present form

\section{Availability of data and materials}

Not applicable

\section{Competing interests}


There are no conflicts to declare.

\section{Funding}

There is no Funds for this study (Not applicable)

\section{Authors' Contributions}

Mohamed Fathy Ahmed; conceptualization, perform the agricultural experiments on the P. alba and manuscript revision. Mostafa Ahmed Ibrahim; synthesis of nanomaterials. Ahmed Sadek Mansour, synthesis of nanomaterials, and manuscript revision. Ahmed Nabile Emam (Corresponding author); performing characterization experiments, data analysis, and formulating and revision of the manuscript. Ashraf Bakry Abd El-Razik; conceptualization, performing genetic experiments, and contributing to the writing and revision of the manuscript. Eman Tawfik; conceptualization, contribution in performing the agricultural \& genetic experiments, and contributing to the writing of the manuscript.

\section{Acknowledgment}

The authors are grateful to Dr. Aisha Mostafa and Dr. Amal Farouk at X-Ray Crystallography laboratory in National Research Centre (NRC) for performing XRD measurements of as-prepared metal oxide nanoparticles using Bruker D8 advance X-Ray Powder Diffractometer.

\section{References}

Aitchison EW, Kelley SL, Alvarez PJ, Schnoor JL (2000): Phytoremediation of 1, 4-dioxane by hybrid poplar trees. Water Environment Research 72, 313-321

Al-Khazan MM, Al-Zlabani RM Toxic materials phytoremediation potential of four common trees in Saudi Arabia: A review.

Ali H, Khan E, Ilahi I (2019): Environmental Chemistry and Ecotoxicology of Hazardous Heavy Metals: Environmental Persistence, Toxicity, and Bioaccumulation. Journal of Chemistry 2019, 6730305

Arthur EL, Rice PJ, Rice PJ, Anderson TA, Baladi SM, Henderson KL, Coats JR (2005): Phytoremediation-an overview. Critical Reviews in Plant Sciences 24, 109-122

Asati A, Pichhode M, Nikhil K (2016): Effect of heavy metals on plants: an overview. International Journal of Application or Innovation in Engineering \& Management 5, 56-66

Atteya AK, Genaidy EA, Zahran HA (2018): Chemical constituents and yield of Simmondsia chinensis plants as affected by foliar application of gibberellic acid and zinc sulphate. Bioscience Research 15, 1528-1541

Becker M, Asch F (2005): Iron toxicity in rice-conditions and management concepts. Journal of Plant Nutrition and Soil Science 168, $558-573$

Bojarczuk K (2004): Effect of Toxic Metals on the Development of Poplar(Populus tremula L. x P. alba L.) Cultured in vitro. Polish Journal of Environmental Studies 13, 115-120

Briffa J, Sinagra E, Blundell R (2020): Heavy metal pollution in the environment and their toxicological effects on humans. Heliyon 6, e04691

Campbell AM (1997): DNA Technology in the Classroom: A Circular Map of a Bacterial Plasmid. The American Biology Teacher 59, 164170

Castiglione S, Franchin C, Fossati T, Lingua G, Torrigiani P, Biondi S (2007): High zinc concentrations reduce rooting capacity and alter metallothionein gene expression in white poplar (Populus alba L. cv. Villafranca). Chemosphere 67, 1117-1126

Chemingui H, Smiri M, Missaoui T, Hafiane A (2019): Zinc oxide nanoparticles induced oxidative stress and changes in the photosynthetic apparatus in fenugreek (Trigonella foenum graecum L.). Bulletin of environmental contamination and toxicology 102 , 477-485 
Cherian E, Rajan A, Baskar G (2016): Synthesis of manganese dioxide nanoparticles using co-precipitation method and its antimicrobial activity. International Journal of Modern Science and Technology 1, 17-22

Chhipa H (2019): Applications of nanotechnology in agriculture. Methods in Microbiology 46, 115-142

DeRosa MC, Monreal C, Schnitzer M, Walsh R, Sultan Y (2010): Nanotechnology in fertilizers. Nature nanotechnology 5, 91-91

Di Lonardo S, Capuana M, Arnetoli M, Gabbrielli R, Gonnelli C (2011): Exploring the metal phytoremediation potential of three Populus alba L. clones using an in vitro screening. Environmental Science and Pollution Research 18, 82-90

Djingova R, Kuleff I (2000): Instrumental techniques for trace analysis in Trace Elements: Their Distribution and Effects in the Environment, JP Vernet, Ed. Elsevier, London, UK

El-Sayed IM, Shaaban SA, Taha LS, Mahgoub MH (2019): ANATOMICAL STRUCTURE AND MICROPROPAGATION ABILITY OF POPULUS ALBA L. UNDER EFFECT OF DROUGHT STRESS. Plant Archives 19, 2655-2663

Gautam A, Dubey RS (2018): Metal toxicity in plants: Induction of oxidative stress, antioxidative defense system, metabolic alterations and phytoremediation. Molecular physiology of abiotic stresses in plant productivity, 256-290

Gheith E-SMS, Shafik MM, El-Badry OZ, Kareem BMA (2018): Growth and productivity of maize (zea mays L.) as affected by nitrogen and zinc fertilizer levels: 1. Growth analysis. BIOSCIENCE RESEARCH 15, 54-59

Gomes DG, Pieretti JC, Rolim WR, Seabra AB, Oliveira HC (2021): 5 - Advances in nano-based delivery systems of micronutrients for a greener agriculture. In: Jogaiah S, Singh HB, Fraceto LF , Lima Rd (Editors), Advances in Nano-Fertilizers and Nano-Pesticides in Agriculture. Woodhead Publishing, pp. 111-143

Gomes MP, Marques TCLLdS, Nogueira MdOG, Castro EMd, Soares ÂM (2011): Ecophysiological and anatomical changes due to uptake and accumulation of heavy metal in Brachiaria decumbens. Scientia Agricola 68, 566-573

Gómez-Sagasti MT, Alkorta I, Becerril JM, Epelde L, Anza M, Garbisu C (2012): Microbial monitoring of the recovery of soil quality during heavy metal phytoremediation. Water, Air, \& Soil Pollution 223, 3249-3262

Hafeez B, Khanif Y, Saleem M (2013): Role of zinc in plant nutrition-a review. Journal of Experimental Agriculture International, 374-391

Hewidy M, Hosni AM, Abdel Razik A, Ahmed MF, Bahnasy M (2019): Morphological, Chemical Characters and Genetic Analysis Discrimination of Five Naturalized Populus Species Inhabiting Four Governorate Territories of Egypt. Arab Universities Journal of Agricultural Sciences 27, 2273-2290

Jaishankar M, Tseten T, Anbalagan N, Mathew BB, Beeregowda KN (2014): Toxicity, mechanism and health effects of some heavy metals. Interdiscip Toxicol 7, 60-72

Kališová-Špirochová I, Punčochářová J, Kafka Z, Kubal M, Soudek P, Vaněk T (2003): Accumulation of heavy metals by in vitro cultures of plants. Water, Air and Soil Pollution: Focus 3, 269-276

Katanic M, Pilipovic A, Orlovic S, Krstic B, Kovacevic B, Pekec S (2008): The influence of nickel, cadmium and lead on the growth of the white poplar clones' shoots in vitro. Proceedings of International scientific conference "Forestry in achieving ...

Koutu V, Shastri L, Malik MM (2016): Effect of NaOH concentration on optical properties of zinc oxide nanoparticles. Materials SciencePoland 34, 819-827

Kovačević B, Orlović S, Rončević S, Miladinović D (2010): The Effect of Silver lon, 1-Naphthalene Acetic Acid and 6-Benzylaminopurine on Micropropagation of" Fastigiate" Tree Shape Variety Populus alba cl. LBM. Acta Horticulturae 885, 197-202

Kumar S, Lakshmanan V-K, Raj M, Biswas R, Hiroshi T, Nair SV, Jayakumar R (2013): Evaluation of wound healing potential of $\beta$-chitin hydrogel/nano zinc oxide composite bandage. Pharmaceutical research 30, 523-537

Laghlimi M, Baghdad B, El Hadi H, Bouabdli A (2015): Phytoremediation mechanisms of heavy metal contaminated soils: a review. Open journal of Ecology 5, 375 
Liu WT, Ni JC, Zhou QX (2013): Uptake of heavy metals by trees: prospects for phytoremediation, Materials Science Forum. Trans Tech Publ, pp. 768-781

Loneragan JF (1988): Distribution and movement of manganese in plants, Manganese in soils and plants. Springer, pp. 113-124

Lu Y, Chanroj S, Zulkifli L, Johnson MA, Uozumi N, Cheung A, Sze H (2011): Pollen tubes lacking a pair of K+ transporters fail to target ovules in Arabidopsis. The Plant Cell 23, 81-93

Marimón-Bolívar W, González EE (2018): Study of agglomeration and magnetic sedimentation of Glutathione@ Fe 304 nanoparticles in water medium. Dyna 85, 19-26

Mishra D, Khare P (2021): Emerging Nano-agrochemicals for Sustainable Agriculture: Benefits, Challenges and Risk Mitigation. In: Kumar Singh V, Singh R, Lichtfouse E (Editors), Sustainable Agriculture Reviews 50: Emerging Contaminants in Agriculture. Springer International Publishing, Cham, pp. 235-257

Morrissey J, Guerinot ML (2009): Iron uptake and transport in plants: the good, the bad, and the ionome. Chem Rev 109, 4553-4567 Naderi M, Abedi A (2012): Application of nanotechnology in agriculture and refinement of environmental pollutants. J Nanotechnol 11, $18-26$

Nair R, Varghese SH, Nair BG, Maekawa T, Yoshida Y, Kumar DS (2010): Nanoparticulate material delivery to plants. Plant science 179, 154-163

Neina D (2019): The Role of Soil pH in Plant Nutrition and Soil Remediation. Applied and Environmental Soil Science 2019, 5794869

Oleksyn J, Karolewski P, Giertych M, Werner A, Tjoelker M, Reich P (1996): Altered root growth and plant chemistry ofPinus sylvestris seedlings subjected to aluminum in nutrient solution. Trees 10, 135-144

Parmar S, Singh V (2015): Phytoremediation approaches for heavy metal pollution: a review. J Plant Sci Res 2, 135

Prasad T, Sudhakar P, Sreenivasulu Y, Latha P, Munaswamy V, Reddy KR, Sreeprasad T, Sajanlal P, Pradeep T (2012): Effect of nanoscale zinc oxide particles on the germination, growth and yield of peanut. Journal of plant nutrition 35, 905-927

Pulford I, Watson C (2003): Phytoremediation of heavy metal-contaminated land by trees-a review. Environment international 29, 529540

Raskin I, Kumar PN, Dushenkov S, Salt DE (1994): Bioconcentration of heavy metals by plants. Current Opinion in biotechnology 5, 285290

Reeves RD (2000): Metal-accumulating plants. Phytoremediation of toxic metals: using plants to clean up the environment

Rengel Z (2015): Availability of Mn, Zn and Fe in the rhizosphere. Journal of soil science and plant nutrition 15, 397-409

Rout GR, Sahoo S (2015): ROLE OF IRON IN PLANT GROWTH AND METABOLISM. Reviews in Agricultural Science 3, 1-24

Sadak MS, Bakry BA (2020): Zinc-oxide and nano ZnO oxide effects on growth, some biochemical aspects, yield quantity, and quality of flax (Linum uitatissimum L.) in absence and presence of compost under sandy soil. Bulletin of the National Research Centre 44, 98

Sampathkumar K, Tan KX, Loo SCJ (2020): Developing Nano-Delivery Systems for Agriculture and Food Applications with NatureDerived Polymers. iScience 23, 101055

Sarkar N, Chaudhary S, Kaushik M (2021): Nano-fertilizers and Nano-pesticides as Promoters of Plant Growth in Agriculture. In: Singh P et al. (Editors), Plant-Microbes-Engineered Nano-particles (PM-ENPs) Nexus in Agro-Ecosystems: Understanding the Interaction of Plant, Microbes and Engineered Nano-particles (ENPS). Springer International Publishing, Cham, pp. 153-163

Shirani Bidabadi S (2020): The role of Fe-nano particles in scarlet sage responses to heavy metals stress. International journal of phytoremediation $22,1259-1268$

Singh B, Schulze D (2015): Soil minerals and plant nutrition. Nature Education Knowledge 6, 1

Page $11 / 17$ 
Tawfik M, Bakhoum G, Sadak Mervat S, Kabesh M (2017): Application of ZnO nanoparticles for sustainable production of Atriplex halimus in saline habitats. Bull NRC 41, 286-305

Tchounwou PB, Yedjou CG, Patlolla AK, Sutton DJ (2012): Heavy metal toxicity and the environment. Exp Suppl 101, 133-164

Usman M, Farooq M, Wakeel A, Nawaz A, Cheema SA, ur Rehman H, Ashraf I, Sanaullah M (2020): Nanotechnology in agriculture: Current status, challenges and future opportunities. Science of the Total Environment 721, 137778

Van Assche F, Clijsters H (1990): Effects of metals on enzyme activity in plants. Plant, Cell \& Environment 13, 195-206

Wintz H, Fox T, Vulpe C (2002): Responses of plants to iron, zinc and copper deficiencies. Biochemical Society Transactions 30, 766-768

Yang X-C, Shang Y-L, Li Y-H, Zhai J, Foster NR, Li Y-X, Zou D, Pu Y (2014): Synthesis of Monodisperse Iron Oxide Nanoparticles without Surfactants. Journal of Nanomaterials 2014, 740856

Zhang P, Guo Z, Ullah S, Melagraki G, Afantitis A, Lynch I (2021): Nanotechnology and artificial intelligence to enable sustainable and precision agriculture. Nature Plants 7, 864-876

\section{Figures}
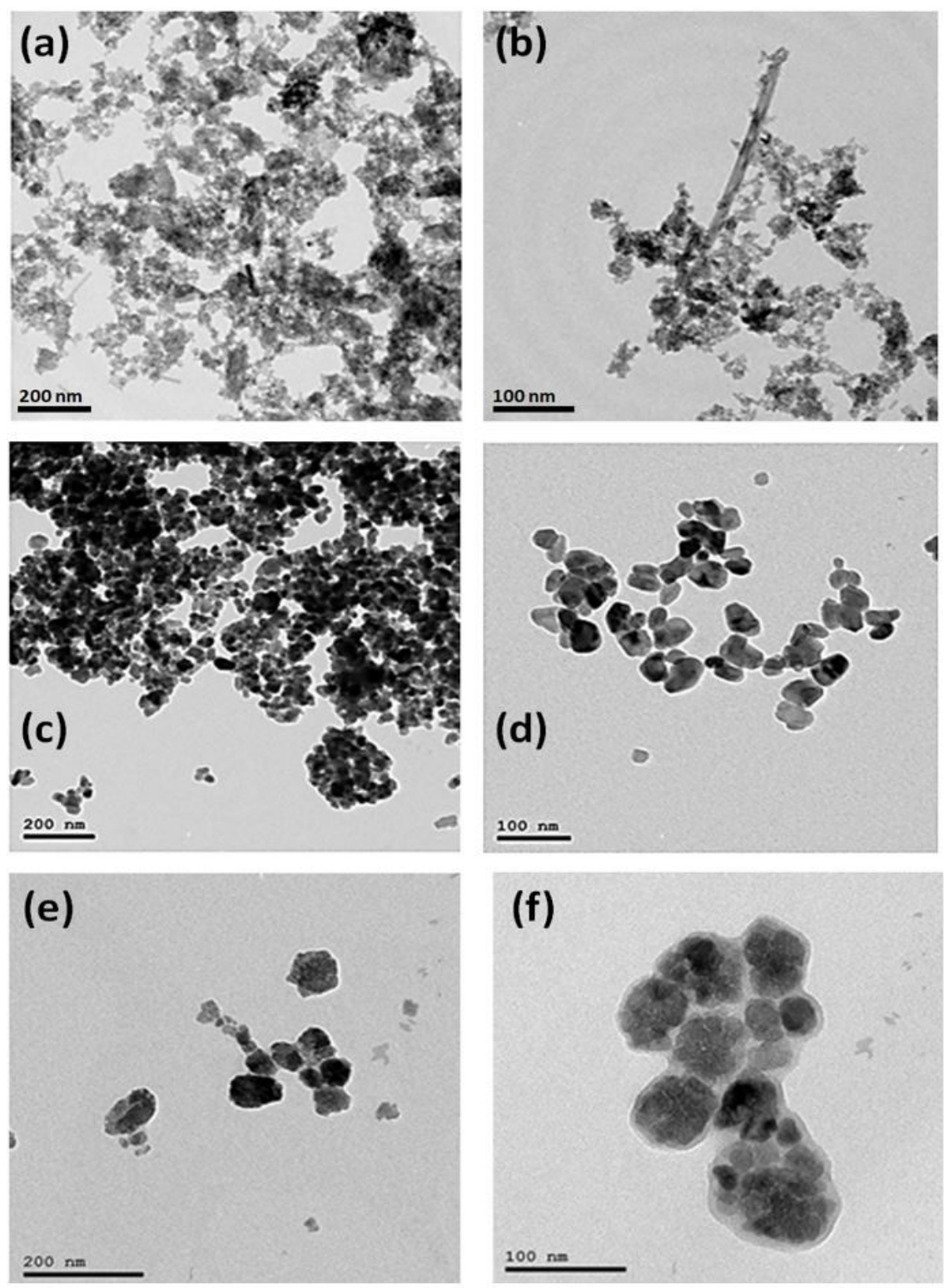

Figure 1 


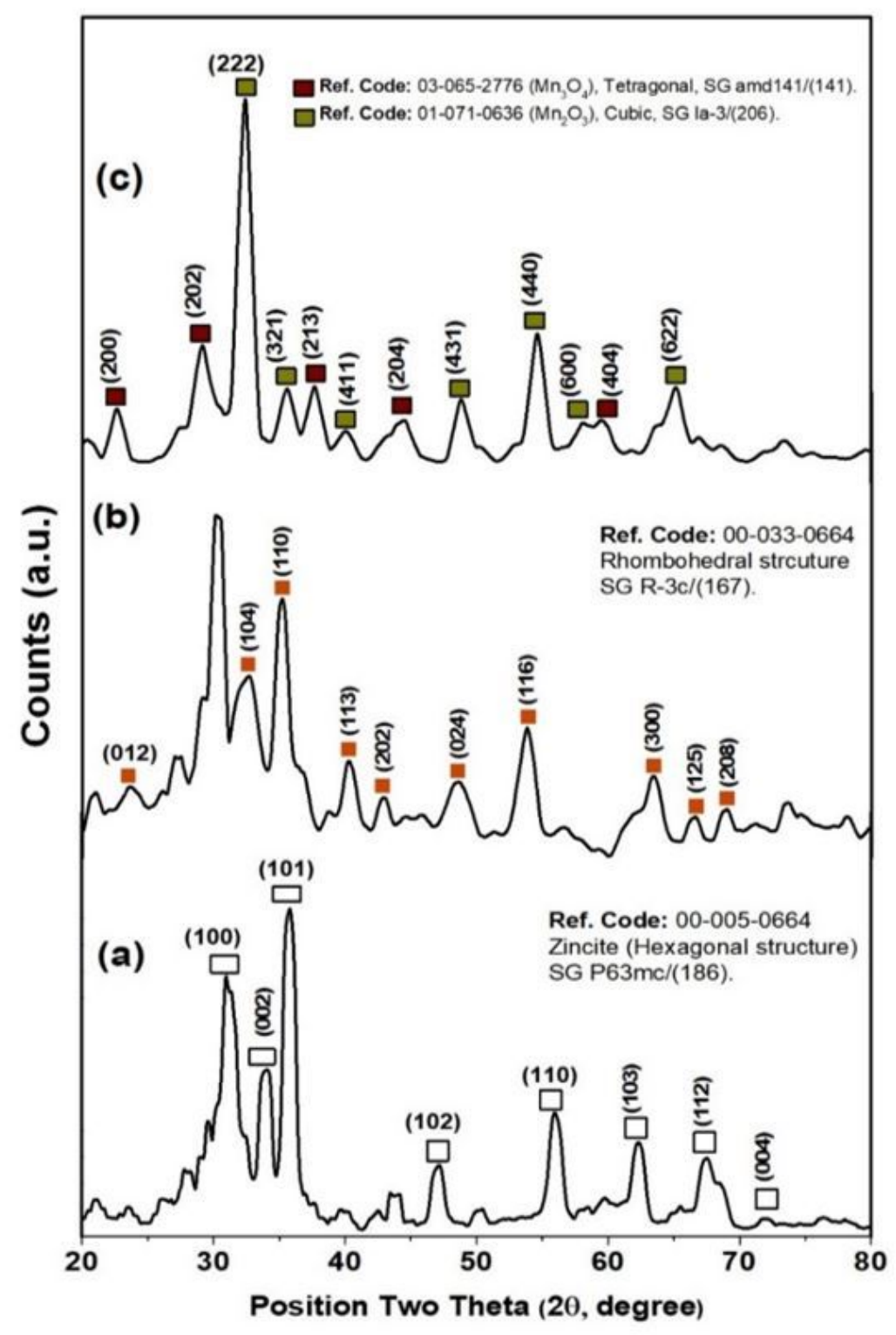

Figure 2

XRD patterns of ZnO (a), Fe2O3 (b) and Mn2O3 (c) nanoparticles. 

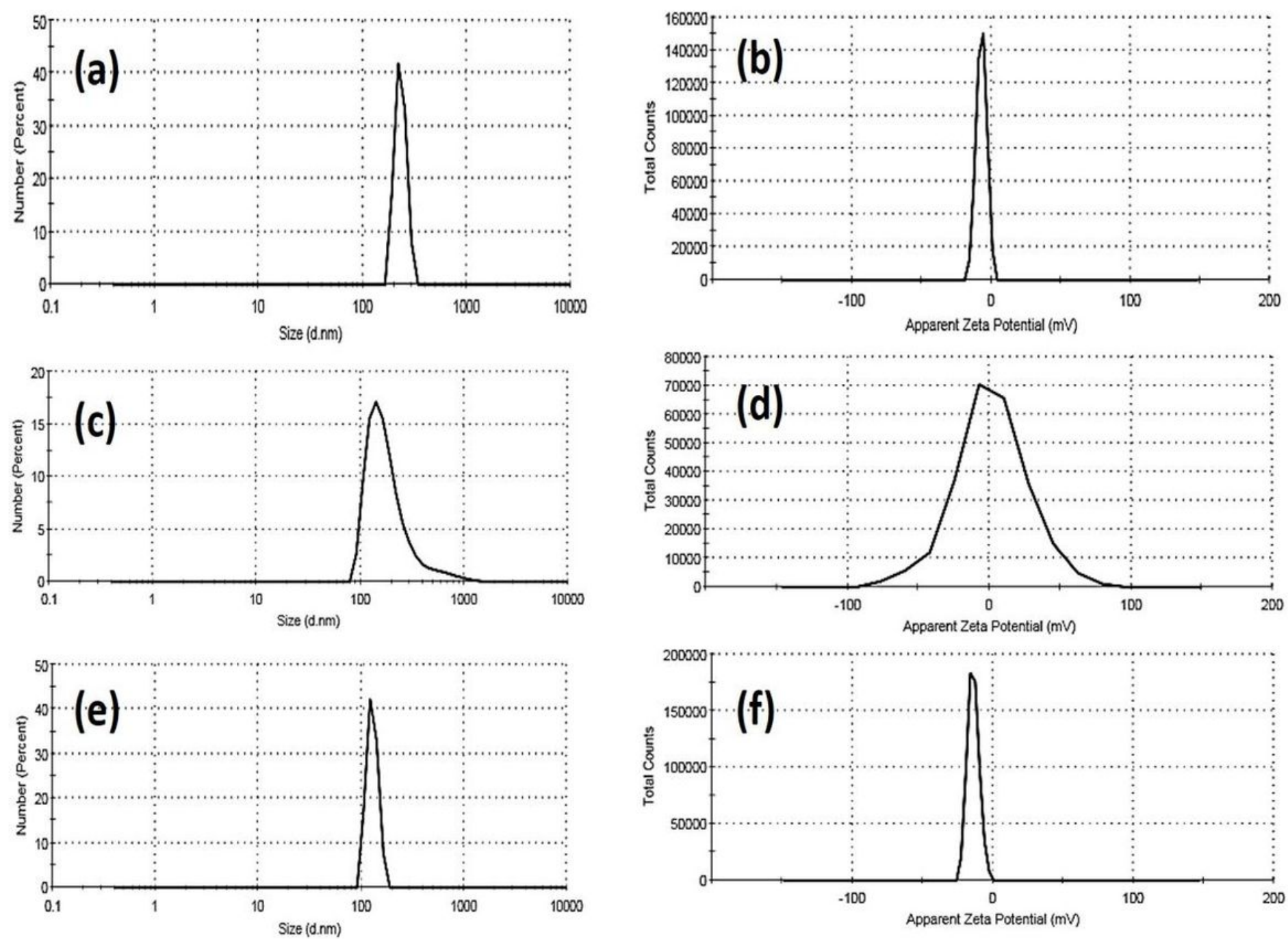

Figure 3

DLS and Zeta-potential data of Fe2O3 (a \& b), ZnO (c \& d) and Mn2O3 (e \& f) nanoparticles. 


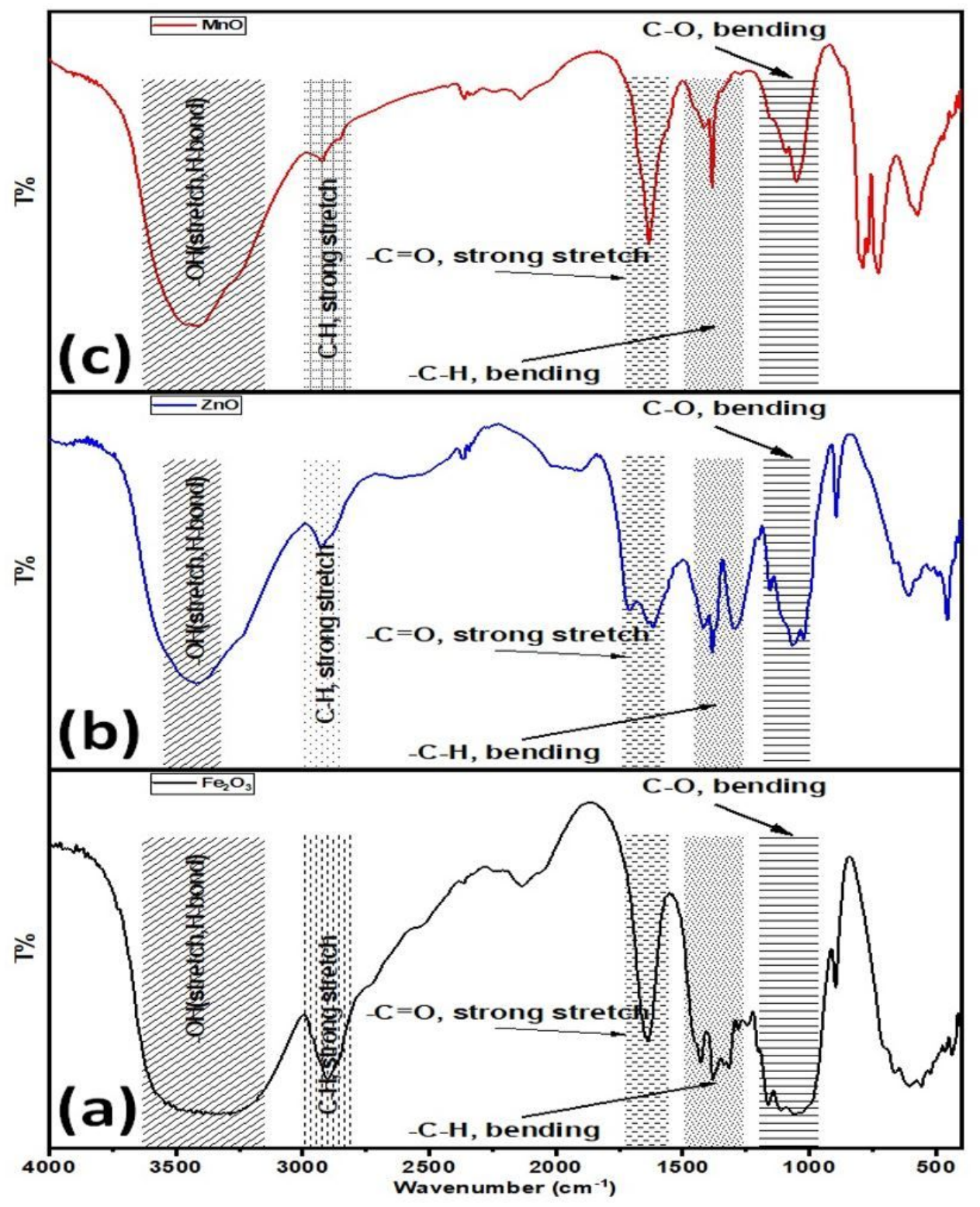

Figure 4

FT-IR for Fe2O3 (a), ZnO (b) and Mn2O3 (e) nanoparticles.

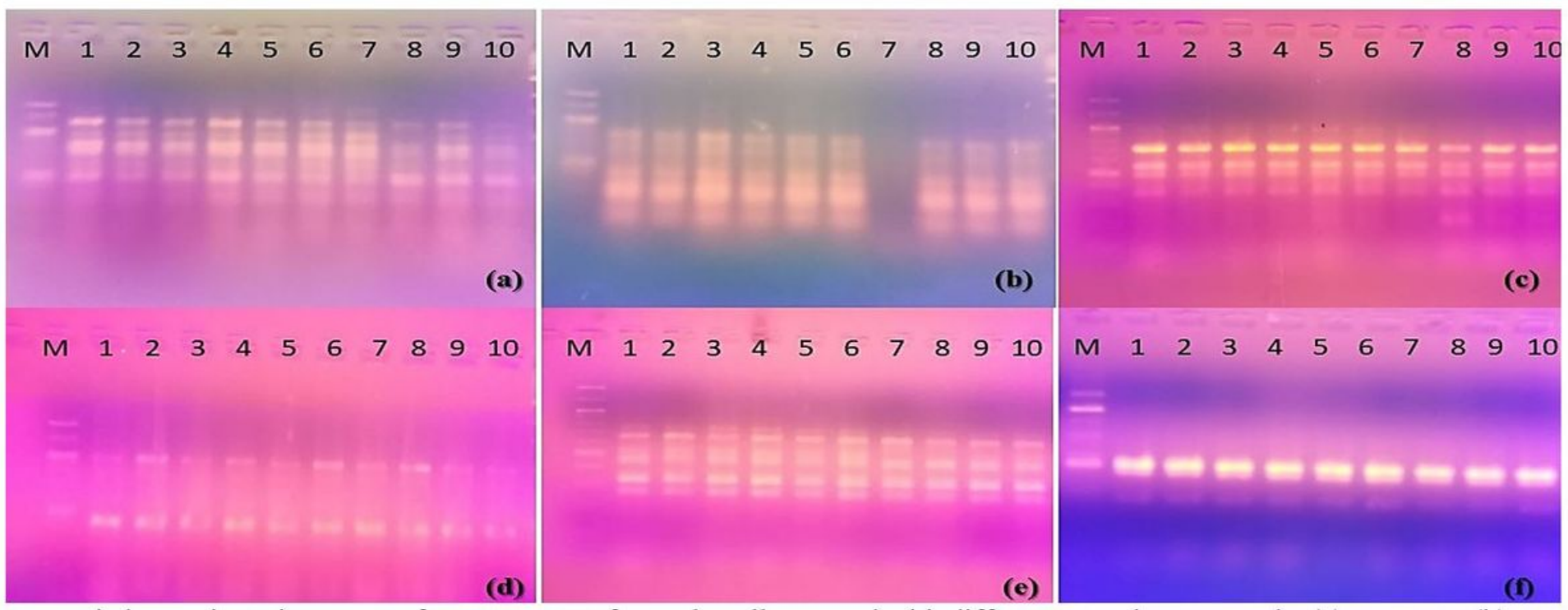




\section{Figure 5}

Gel electrophoresis pattern of RAPD-PCR of Populus alba treated with different nano-heavy metals. (a) Deca-12; (b) Deca-13; (c): Deca11; (d) Deca-7; (e) Deca-4; (f) Deca-10. (M: 100-base pair ladder; 1: 20 mg/L Fe; 2: 40 mg/L Fe; 3: 60 mg/L Fe; 4: 20 mg/L Zn; 5: 40 mg/L Zn; 6: 60 mg/L Zn; 7: 20 mg/L Mn; 8: 40 mg/L Mn; 9: 60 mg/L Mn; 10: control)
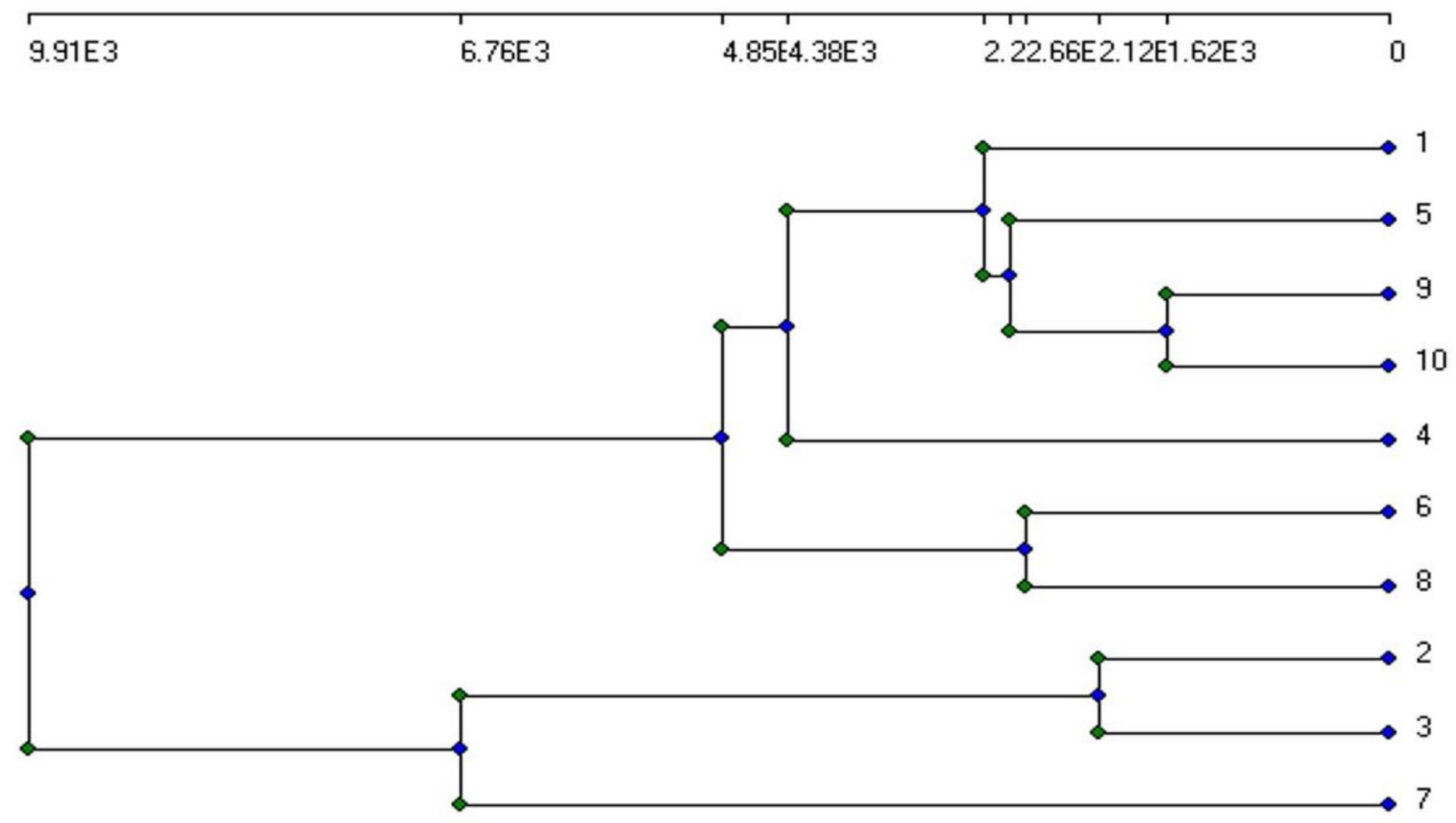

\section{Figure 6}

Total phylogenetic tree of Populus alba treatments with different nano-heavy metals, resulted from all morphological parameters, chlorophyll index and genetic variation. (1: 20 mg/L Fe; 2: 40 mg/L Fe; 3: 60 mg/L Fe; 4: 20 mg/L Zn; 5: 40 mg/L Zn; 6: 60 mg/L Zn; 7: 20 mg/L Mn; 8: 40 mg/L Mn; 9: 60 mg/L Mn; 10: control) 


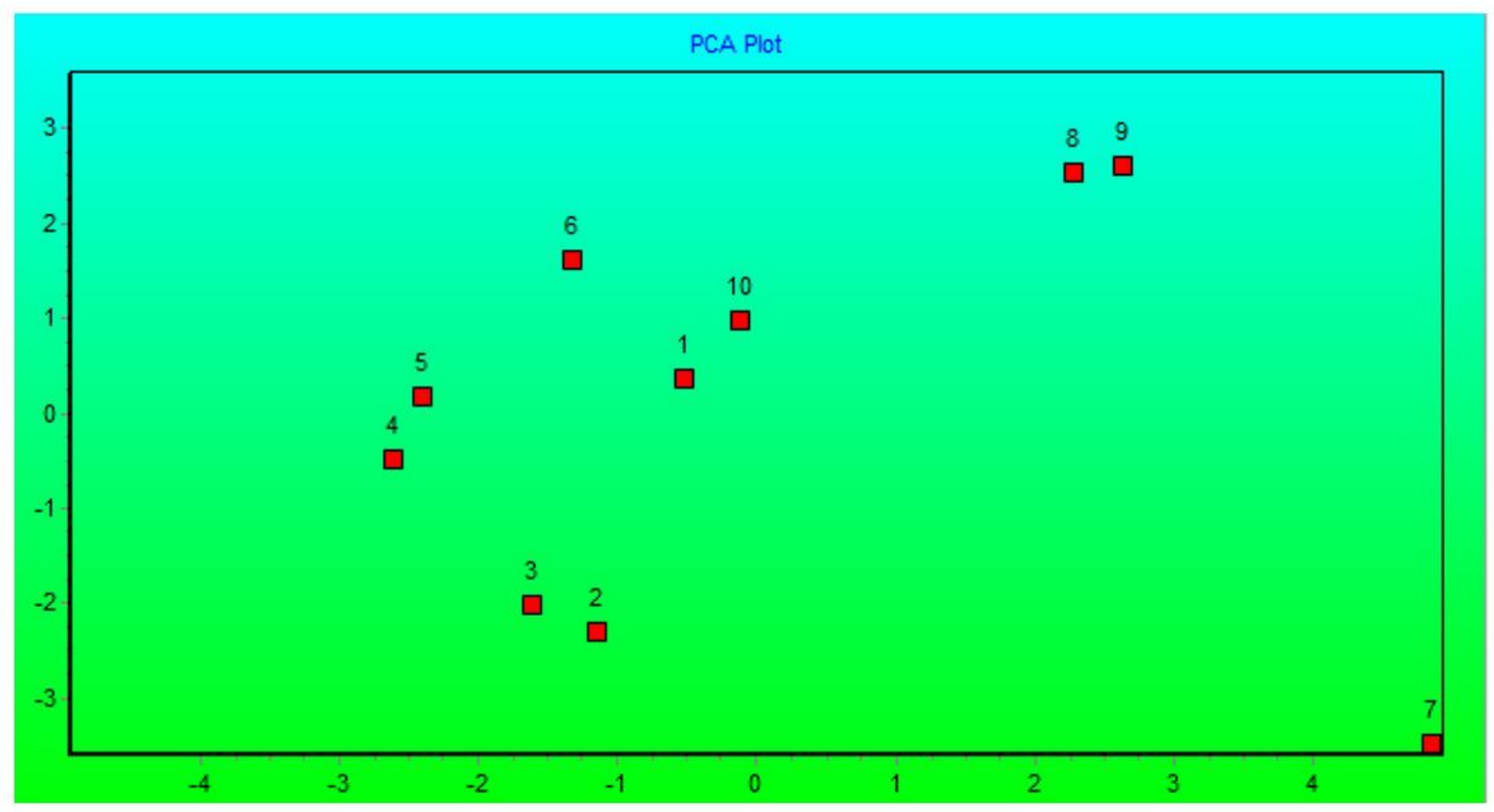

Figure 7

PCA blot showing correlation among nano-heavy metals treatments of Populus alba. (1: $20 \mathrm{mg} / \mathrm{L} \mathrm{Fe;} 2: 40 \mathrm{mg} / \mathrm{L} \mathrm{Fe;} 3: 60 \mathrm{mg} / \mathrm{L} \mathrm{Fe}$;: 20 mg/L Zn; 5: 40 mg/L Zn; 6: 60 mg/L Zn; 7: 20 mg/L Mn; 8: 40 mg/L Mn; 9: 60 mg/L Mn; 10: control) 